\title{
Economic and Legal Analysis of Cryptocurrency: Scientific Views from Russia and the Muslim World
}

\author{
Shamil Shovkhalov ${ }^{1,2}$ and Hussein Idrisov $1,3, *$ (D) \\ 1 Department of Legal Disciplines, Chechen State Pedagogical University, 364024 Grozny, Russia; \\ shovkhalov.shamil@gmail.com \\ 2 Department of Accounting, Analysis and Auditing, Siberian Federal University, 660041 Krasnoyarsk, Russia \\ 3 Department of Civil Law and Procedure, Chechen State University, 364024 Grozny, Russia \\ * Correspondence: huseyn23@rambler.ru
}

check for updates

Citation: Shovkhalov, Shamil, and Hussein Idrisov. 2021. Economic and Legal Analysis of Cryptocurrency: Scientific Views from Russia and the Muslim World. Laws 10: 32. https:// doi.org/10.3390/laws10020032

Received: 19 April 2021

Accepted: 7 May 2021

Published: 10 May 2021

Publisher's Note: MDPI stays neutra with regard to jurisdictional claims in published maps and institutional affiliations.

Copyright: (c) 2021 by the authors. Licensee MDPI, Basel, Switzerland. This article is an open access article distributed under the terms and conditions of the Creative Commons Attribution (CC BY) license (https:/ / creativecommons.org/licenses/by/ $4.0 /)$
Abstract: The article is devoted to the analysis of cryptocurrency as a new phenomenon in the modern global economic processes and legal institutions. The relevance of the study is predetermined by the very specifics of such a phenomenon as cryptocurrency consisting of a distributed ledger technology, which determines the peculiarities of issuing, storing and performing operations with cryptocurrency. Moreover, the cryptocurrency turnover directly correlates with the national legislation of individual countries, which are the subject of domestic regulation with currency, tax legislation and legislation on the securities market. Sometimes, in this regard, there is a clash of public interests and the interests of entities involved in the circulation of cryptocurrencies. Cryptocurrency, as an unconventional, trendy phenomenon of the recent times, has become the object of research and discussions on all the world platforms, starting with academia, continuing with the business community and ending with state institutions. There are many reasons for explaining such interest and they can all be reduced to two main blocks: the advantages and the disadvantages of cryptocurrency circulation. The problem of cryptocurrency turnover, on the one hand, is that until now none of the national economies have regulated the cost-effective mechanism for the cryptocurrency turnover and, on the other hand, the leading countries have not yet set up an effective system of legal regulation of cryptocurrency. Many countries are in the active process of working to adequately address the above problem. Separately, it is worth highlighting the interest of Muslim countries in this issue, where discussions are still underway about the permissibility of cryptocurrency in Islamic law. As for the Russian realities in the context of the issue under study, the Federal Law "On Digital Financial Assets, Digital Currency and on Amendments to Certain Legislative Acts of the Russian Federation", which came into effect on 1 January 2021, was supposed to streamline relations of subjects including cryptocurrencies, but, according to the experts in this field, this law is far from impeccable and this sphere of relations cannot be quickly and effectively regulated. This article describes the characteristics of cryptocurrency, its essence, disadvantages and advantages as an object of economic and civil law relations. The purpose of the research is to analyze the economic and legal phenomenon of cryptocurrency, as well as its characteristics in the Muslim legal system. The complexity of the work should be emphasized as a novelty. Based on the designated goal and the logic of construction, the study consists of three interrelated parts. The first part outlines the characteristics of cryptocurrency as an economic category, the second part is devoted to its legal analysis and the last part of the study demonstrates the Islamic perception (Sharia analysis) of this phenomenon. As a conclusion on the scientific research, we will highlight the following provisions. First, economically, nowadays, cryptocurrency is a rather controversial financial instrument: on the one hand, it has great investment attractiveness, but on the other hand, it is subject to great volatility and seems to be a rather risky financial asset. Secondly, from a legal standpoint, cryptocurrencies have not yet found their consistent consolidation and further legal regulation in the Russian legislation. It seems that the legal regulation of this institution will systematically develop depending on what application and results of its turnover the cryptocurrency will have in the future. Finally, the Islamic interpretation of the cryptocurrency phenomenon boils down to the absence of a single, consistent explanation of it from the perspective of Islam and Sharia as an object of permissibility (or prohibition) of transactions with it. It is necessary to further analyze 
the practice of using cryptocurrency and its impact on the economy and legal institutions in order to make a final decision on its permissibility or prohibition in correlation with the types of activity and the upcoming consequences associated with it.

Keywords: cryptocurrency; bitcoin; money; currency; mining; law; code; responsibility; Islam; Sharia; Islamic economics

JEL Classification: K15; K24

\section{Introduction}

This century can be called the century of post-information technologies which have completely identified a new approach to information and to its processing, use and transmission. Nowadays, information is not just a source of knowledge within the educational system, but also a commodity. Information technology today literally "permeates" all human aspects of activity. These issues include circulation of funds between the entities of financial relations.

As part of the development of information technology, a new kind of financial instrument, cryptocurrency, has emerged and developed recently. It is no secret that today the legal regulation of cryptocurrency is relevant, as the distributed ledger technology is a specific feature that determines the features of release, storing, and performing cryptocurrency transactions. The circulation of cryptocurrency correlates with the legislation that is the subject of national regulation in the field of money circulation, taxes, and legal regulation of the stock market. Often, this relationship is highlighted with mutual contradictions and in some places with an open clash of systemic principles and approaches in the formulation and practical application of these financial market instruments.

Cryptocurrency as a specific financial instrument has a number of advantages, including:

(1). Acceleration, cost reduction and significant simplification of settlements between entities, since the scheme excludes "unnecessary" intermediaries;

(2). Protection from inflationary processes;

(3). Amount of issued bitcoins grows at a predetermined rate, unlike public money printed by the government at its own discretion (Swan 2017).

Along with the indicated advantages of cryptocurrency, some researchers highlight a number of others: stimulating digitalization, reducing environmental impact, etc. However, they also have the disadvantage that cryptocurrencies eliminate the privacy of transactions and pose a risk to the traditional banking sector (Echarte Fernández et al. 2021).

Until recently, the circulation of cryptocurrencies in the territory of the Russian Federation had been in limbo. The state tried to determine the issue of an approach to the legal regulation of this new financial and legal institution and sometimes its reaction (including the legislator) was reduced to making rash, contradictory and practically ineffective decisions (Yankovsky 2020). However, on 1 January 2021, a new law came into force regulating relations concerning issuance, accounting and circulation of digital financial assets ${ }^{1}$. The provisions of this law have already received a rather contradictory assessment by the expert community, although it is not yet approved by the enforcement practice. Nevertheless, it is still premature to talk about efficiency or, on the contrary, about insufficient regulation of this law, because there is still no established enforcement practice.

Cryptocurrency has become the first implementation of the "Blockchain" technology and its potential is not limited to a payment system. Decentralized applications created on its basis are able to influence such areas of life as economics, science, education, art, culture,

1 On digital financial assets, digital currency and on amendments to certain legislative acts of the Russian Federation: Feder. Law of 31.07.2020 No. 259-FL. Available online: http:/ / www.consultant.ru (accessed on 16 January 2021). 
etc. Possible ways to the develop the technology are as follows: cryptocurrencies exchange, all types of financial transactions, properties, registers of government documents, smart contracts.

The analysis of regulatory legal acts that is currently emerging demonstrates a change in the restrictive attitude to the legal regulation of cryptocurrencies for targeted regulation of the most problematic and urgent issues for the state economy (taxes and fees, currency regulation and control, legalization (laundering) of income, etc.).

The above circumstances predetermine the relevance of research on the circulation of cryptocurrency as a new economic instrument and an object of civil rights.

The content of this work structurally consists of three logically interrelated parts. The first part describes the characteristics of cryptocurrency as an economic category, the second part is devoted to its legal analysis, and the last part of the study demonstrates the Sharia analysis of this phenomenon.

\section{Cryptocurrency as an Economic Category}

\subsection{Theory}

The history of money emergence and its development has experienced a number of serious changes that were once revolutionary. Today it is no longer surprising that a very significant part of all payments in the world (especially in developed countries) is made as cashless settlement. Therefore, in the last decade a vigorous discussion of a new phenomenon, namely cryptocurrency, fits well within the historical events. The fact that the number of different cryptocurrencies has long exceeded one thousand should be perceived as a signal that can radically change the understanding and attitude towards money in the future.

The modern understanding of the money phenomenon begins its history at the end of the 17th century, when the Bank of England was created, which was, in fact, the first central bank of issue. One of its tasks was to finance the country's debt; as part of resolving this issue, government contributions were placed in it. Along with this, other important tasks were solved, including the introduction of banknotes. In the same way, up to the 19th century in different countries there was a rapid transition from private money to the creation of a single institution that provided currency based on silver or gold standards until the summing up of the Bretton Woods Conference of 1944.

In the XX century, non-cash settlements began to spread actively, then electronic money appeared, and only then the whole world learned about bitcoin. Just a few years ago, when its cost was many times less, experts estimated the capitalization of this cryptocurrency at USD 44 billion (Sazhina and Kostin 2018). Bitcoin appeared at the turn of 2008-2009 and one BTC cost USD 0.001, then in 2011 this rate reached parity origins of 1 BTC $=$ USD 1 , and later this rate reached more than USD 40,000 for $1 \mathrm{BTC}^{2}$. Indeed, the current bitcoin ${ }^{3}$ rate is several times higher than the data from 2018, and the fact of rapid growth deserves special attention, taking into account the increase in types from one cryptocurrency to an enormous flow of new ones, as well as the fact that along with their introduction a number of innovations in the financial sector appeared (Shevchenko 2018) as a certain phenomenon in the economy (Shcherbik 2017). On the other hand, a number of scientists negatively perceive these trends, calling cryptocurrency a gamble (Kurylenok 2019) or a bubble that has value only in the course of an exchange (Ushakova 2019), and The European Central Bank has generally declared a threat to price stability ${ }^{4}$. The impossibility of mass use and adoption of cryptocurrencies may cause the transformation of "private money" into a money surrogate or into a bursting soap bubble. In this connection, the statement of A. Carstens, the General Manager of the Bank for International Settlements (BIS), seems to

2 Bitcoin rate. Available online: https://www.rbc.ru/crypto/currency/btcusd (accessed on 6 February 2021).

3 Note: At the time of writing, 1 Bitcoin was valued at USD 58,000.

4 Opinion of the European Central Bank of 12.10.2016 (con/2016/49). P. 1.1.2. Available online: www.ecb.europa.eu/ecb/legal/pdf/en_con_2016_49_ f_sign.pdf/ (accessed on 2 February 2021). 
be fair to some extent: "Bitcoin has become a combination of a soap bubble, a financial pyramid and an environmental disaster ${ }^{5 "}$.

Today it is difficult to regulate cryptocurrency, that is, to control it. Exceptions to the rule are cases when some states consider cryptocurrency as a full-fledged means of payment. In Japan, since 2017, cryptocurrency has received the status as means of payment ${ }^{6}$. An example of a backlash is the experience of Bolivia, Ecuador, Bangladesh, Kyrgyzstan and Nepal, where the circulation of cryptocurrencies is completely prohibited ${ }^{7}$.

At the same time, the idea of private money that famous economists of the past spoke about in their works again began to persist in the economic arena of scientific thought. In an interview given back in 1999, M. Friedman said: "The only thing lacks, but soon to appear is reliable electronic money. It will be possible to transfer funds on the Internet from " $A$ " to " $B$ ", despite the fact that " $A$ " will not know " $B$ " and " $B$ " will not know " $A$ ". I can take a $\$ 20$ bill, give it to you, and there's no record of where it came from. You can get money without even knowing who I am. This kind of thing will appear on the internet. And they will make life easier for those who use them ${ }^{8}$."

Modern proponents of the cryptocurrency spread are using the ideas of these scientists. According to F.A. Hayek, in perfect conditions it is necessary competition in terms of money issue and various institutions need it, not just central state banks (Hayek 1996). In the meantime, modern scientists claim that denationalization of money is Hayek's monetary legacy, and he would reject the idea that bitcoin are currencies that could be accepted massively by the market (Sanz Bas 2020). However, even these ideas, half a century later, have changed because cryptocurrency is a set of digital "coins" stored in wallets, which together form the work of a round-the-clock bank.

As you know, the first commercially successful cryptocurrency was bitcoin. Since its code is open, many, taking it as a basis, introduced other currencies, and later completely new ones appeared: "capricoin", "primecoin", "lightcoin", "peercoin", etc.

The essence of bitcoin production is to solve the problem by the brute-force method, when a finite number of system states are considered in order to establish the truth of the statement. In the course of hashing, information of any size is entered, and the output is a code. The number of monetary units, or so-called "crypto-coins", in the system is limited to 21 million virtual units. The process of using the computing power in order to create a set of operations is called mining. To date, miners have "mined" about $60 \%$ of the total number of bitcoins possible for mining.

There are several ways to produce cryptocurrency:

- Installation of a special program on a computer with sufficient video card power;

- Installation of special equipment and the creation of a so-called farm;

- Powerful computer stations to ensure the smooth operation of the system;

- Entering the pool-a server that unites a certain number of devices into a single whole with the subsequent division of the cryptocurrency in proportion to the performance, depending on the power of the equipment.

In a simplified way, the movement of a cryptocurrency can be described by the following algorithm:

1. One party sends from their wallet a hash-encrypted cryptocurrency in the form of a transaction block.

2. This block is sent to the rest of the subjects in order to establish its validity, that is, verification.

5 The Economist. Available online: https://www.economist.com/news/finance-and-economics/21736556-indeed-cryptoplunges-make-other-assetprices-look-tame-bitcoin-and-its-rivals (accessed on 28 February 2021).

6 In Japan, a law that recognizes bitcoins as a means of payment came into force. Available online: https://www.rbc.ru/rbcfreenews/58df61919a794 76eb3bacbf4 (accessed on 12 January 2021).

7 Five countries where bitcoin is prohibited. Available online: https://cryptocurrency.tech/5-stran-gde-bitkoin-pod-zapretom/ (accessed on 12 January 2021).

8 Nobel laureate Milton Friedman predicted the era of bitcoin 17 years ago. Available online: http:/ /www.invest-rating.ru/expert-opinion/?id=9156 (accessed on 12 January 2021). 
3. The sent block is summed up with the rest in case of validation.

4. The cryptocurrency is transferred to the second party wallet.

\subsection{Discussion}

One should examine the key disadvantages of cryptocurrency distribution, highlighted by a various authors and specialists in the field of economics, and also present a number of counterarguments for a balanced assessment.

1. Development of the shadow economy, leading to tax evasion, which basically destroys the idea of an integral state.

This is quite a controversial argument, because a number of countries have already adopted relevant amendments to the legislation that provides a solution to the alleged problem. As a matter of fact, postponing discussion of this issue at the legislative level brings negative results. This means that it is a matter of effective economic policy, for the shadow economy includes many phenomena, and the rejection of some tools does not entail an improvement in the situation; on the contrary, it is an attempt to avoid solving the issue. If any state declares that the fight against the turnover of the cryptocurrency is more profitable economically rather than its regulation, then it is necessary to advance appropriate arguments, motivations, and calculations so that the public could take this decision as a basis. However, practice is not on the side of prohibitions. We can recall the speech of the Mayor of Miami, who announced the lost profit linked with the late decision to invest the city funds in cryptocurrency ${ }^{9}$. In general, according to some scientists, cryptocurrency could speed up, reduce the cost and simplify calculations by excluding traditional financial institutions from them (Nedorezkov 2017).

2. Unsecured cryptocurrency.

This argument does not withhold any scrutiny, since all the world's leading currencies have not been backed by any gold, goods, services, etc. for many decades. However, even if it is moved into the stage of economic discussion, then it is enough to remember that today all cryptocurrencies can be divided into unsecured and secured ones, which are also called "crypto assets". For example, the creators of such a cryptocurrency as "ZrCoin" bound the price of 1 token to $1 \mathrm{~kg}$ zirconium dioxide (Sazhina and Kostin 2018). With regard to this kind of cryptocurrency, economists argue that they are real assets, since they are not the financial liabilities of any economic agent (Rallo 2019).

3. Inability to trace participants in financial transactions (anonymity, laundering of criminal proceeds, financing of crime, fraudulent activities, etc.).

The anonymity of participants mediates the spread of criminal transactions and, therefore, there are no tools to combat this, such as the ability to freeze accounts and other restrictions on participants in financial transactions. Anonymity is ensured due to the absence of any logins and personal data of the contacting parties in the wallets. Transaction is possible only if there is an identifier. The wallet is a consequence of the cryptographic function. All "actors" agree that anonymity is rather a positive characteristic of a cryptocurrency. Here again the question of normative legal regulation arises and this denial will only exacerbate the situation with the criminal actions of individual entities.

4. High volatility of the exchange rate.

Cryptocurrency is attractive as a tool for financial speculation and is characterized by rather sharp, unpredictable "jumps/hikes" in the rate, usually caused by speculative demand.

Even a single post on the social network of someone powerful significantly increases the value of the cryptocurrency. At the time of writing, the cost of bitcoin has reached over USD 50,000 and experts attributed this to the message of the CEO of MicroStrategy about

9 Mayor of Miami: it was necessary to invest part of the treasury in bitcoin a year ago. Available online: https://www.rbc.ru/crypto/news/60017938 9a7947315e9d5a90 (accessed on 25 February 2021). 
the purchase of another 328 bitcoins for the amount of USD 15 million (the company's total investment portfolio in cryptocurrency is estimated at USD 2.1 billion), as well as the fact that the clients of the Japanese firm "Rakuten" have the opportunity to settle in cryptocurrency at thousands of outlets, and "PayPal" is planning a deal to acquire the custodian service "Curv" intended for storing cryptocurrencies ${ }^{10}$.

An attempt to represent cryptocurrency as dependent on any variable value stumbles upon an important circumstance in relation to the state currencies. Central banks and their activities are also correlated with many factors, such as financial policy, balance of payments, inflation, the level of international payments and speculative transactions. The more important thing is that decisions can be made as opposed to social welfare, implementing certain tasks of the ruling power. In addition, ineffective policies can often be compensated for by emissions that states can pursue when and how they want (Swan 2017). In this context, there is an opinion that one of the reasons for the rise in prices for some cryptocurrencies lies in the recent distrust of fiat currencies caused by the expansionary monetary policy of the central banks, the leading countries of the world economy (Echarte Fernández et al. 2021). However, the central banks of many countries are showing increasing interest in cryptocurrency in terms of creating their own cryptocurrency, supported by a centralized state banking system. However, as a number of researchers point out, as technology and consumer tastes change, more research is needed to determine what benefits such centralized cryptocurrencies can bring to users in each country and whether these efforts will pay off (Náñez Alonso et al. 2021). F. A. Hayek wrote that only serious competition and the lack of government oversight is a step towards public confidence and strengthening the financial condition of the country (Hayek 1996). Despite the controversy of his thought, it cannot be argued that such an idea is unfounded, especially considering the greater equality of participants in the blockchain system. The criticism of the situation looks objective when the demand and supply of cryptocurrencies differ greatly, which makes the adjustment period unclear. However, it is important to note that even existing traditional mechanisms sometimes fail, especially when it comes to the currency of any country. On the other hand, some financiers note that such an approach is exclusively economic in nature, because cryptocurrency has immunity from surges in energy prices (oil, gas, etc.), the outbreak of wars, geopolitics, and other classical factors (Svetovtseva et al. 2018). Furthermore, for a long time, measures have been taken to smooth out this disadvantage by creating special cryptocurrencies (Chohan 2019).

5. Lack of a mechanism for the redistribution of benefits to solve social challenges.

The modern purpose of cryptocurrency, according to critics, is sheer speculation, enrichment and not a solution of significant social problems.

This thesis fully justifies itself in the current conditions, but do not forget that many cryptocurrencies are limited in production, which means that the probability of excess emission is reduced to zero. For example, the amount of bitcoins cannot exceed 21 million units, while 1 bitcoin equals 100 million "satoshi"11.

Accordingly, the question is about the prospects of cryptocurrency; besides, the speculative nature is at the heart of most financial instruments. According to this logic it is necessary to prohibit the circulation of futures, options and many other financial instruments. The same can be said about the existing asymmetry of information for both investors and issuers (Sazhina and Kostin 2018).

6. Loss of data in a cryptocurrency wallet makes it impossible to withdraw financial assets from it in any other way.

Any cryptocurrency transaction implies a "hash", and then the set of transactions is allocated in the form of a block, which must be confirmed. The cryptocurrency is protected from many problems inherent in the modern banking system, and the network itself is sys-

10 Bitcoin price again exceeded \$50,000. Available online: https:/ /www.rbc.ru/crypto/news / 603de0209a79473018271a46 (accessed on 3 February 2021).

11 Note: Satoshi is the smallest, indivisible unit of the bitcoin cryptocurrency. 
tematically tested on its own. Fraud is only possible during the "ICO" (initial coin offering), as well as dangerous hacker attacks on the payment portal, errors in the address, login, password, and other negative actions. However, the list of threats against cryptocurrency is much smaller compared to ordinary money, because cryptocurrency with its unique code is protected from counterfeiting, which cannot be said about ordinary banknotes. At the same time, it should be emphasized that even if some of the cryptocurrency producers leave the online mode, the activity will not stop. On the other hand, the central state bank can withdraw funds under certain circumstances from any economic entity.

7. Regulatory uncertainty, including illegality in some countries.

Certain countries are against such "money". This is a temporary problem that is being gradually resolved in various countries. The fact that many governments have banned cryptocurrency at the state level is not grounds to refuse it in other countries, but an economic analysis of the emerging processes is needed. However, it is impossible to ignore the principle of legality and ignore the interests of the state in this case. However, the forced restrictive policy of the legislative regulation of cryptocurrencies "discourages" the demand of the system participants for it.

It is interesting that the fact that data enter the blockchain system speaks of their reliability; the other question is the nature of this capital. Therefore, the state, choosing the way of prohibition, seriously slows down the spread of cryptocurrency, since with the increasing number of transactions based on the blockchain system, its popularity will also grow, and the rate should theoretically stabilize. Furthermore, if we take the evolutionary theory of money as a basis, then it is simply necessary to "untie the hands" of the cryptocurrency. In addition, the emerging crypto-exchanges such as Binance, Tokok, Bkex, Fatbtc, MXC and others are a form of regulation, albeit not a state one. Another important argument is the discussion about the possibility of creating your own central bank-backed digital currency (CBDC). According to experts in this area, there are opposite arguments in this matter, making a prediction that the Federal Reserve of the United States of America, the Bank of Japan and the Bank of England will, for the moment, postpone the creation of their own CBDCs, but China, Uruguay, Lithuania and the Bahamas will more likely launch (Náñez Alonso et al. 2020).

8. The ever-increasing complexity of the cryptocurrency production process.

It should be taken into account that large "crypto farms" are developing in China, the USA, the Czech Republic, Iceland, Sweden and other countries, and mining is becoming less accessible for individual (private) actors who do not have sophisticated high-tech equipment due to its high cost. It is assumed that as the complexity of computing operations and the need to use more powerful computing systems in the future increase, mining will become available only for large players in the cryptocurrency market (individual corporations and state entities).

In response to this criticism, it is worth noting that the inherent decentralization of cryptocurrencies, where all information is stored on the devices of wallet owners, minimizes the transaction costs of the financial sector, since banks are less efficient players due to the constant costs of their mediation services, which are incommensurate with the costs of collateral cryptocurrency work. As a result, there is a low cost for transferring one cryptocurrency from one wallet to another. Of course, the modern banking system offers more opportunities and benefits with their ubiquitous ATMs, account maintenance, brokerage accounts and other services, but the blurred boundaries and high mobility in some cases give the blockchain system clear advantages over the classical banking sector.

\subsection{Summary}

Considering the counterarguments for the highlighted shortcomings found in the scientific literature, the results of a survey conducted in 2019 became clear when respondents answered the question regarding the reason for the choice in favor of cryptocurrency and produced the following arguments: 
(1). No influence of inflation-27\%;

(2). Safety-25\%;

(3). Anonymity- $17 \%$;

(4). Open code-14\%;

(5). Availability-12\%;

(6). Low costs-5\% (Shmigidin and Borkova 2019).

Eventually, it is difficult to say what place the cryptocurrency will take in the future of the financial world (Pekhtereva 2018), because even electronic money has not been able to gain significant positions for a couple of decades, although certain changes have recently been made in this direction, especially in terms of the development of the coronavirus pandemic. An important problem seems to be when, as a rule, economists are not directly relevant to the "mining" and all mining processes are concentrated in the hands of IT specialists who may not know the basic economic and financial aspects of the problem under consideration.

\section{Cryptocurrency as a Legal Category}

\subsection{Theory}

As a rule, the first authority response to the phenomenon of cryptocurrency manifested in a negative attitude towards this new financial instrument. This was the case in Russia just a few years ago. The views were repeatedly expressed to prohibit cryptocurrency ${ }^{12}$ and recognize these operations as illegal with a corresponding response from the competent authorities (Golenko and Kislaya 2017). However, these positions were subsequently revised. We proceed from the fact that the official authorities, after weighing all the pros and cons of this financial instrument, and as the entire civilized financial world was inclined to accept the cryptocurrency rather than to reject it, came to a partial solution: it is not expedient to refuse it (in terms of the need for further integration into the world financial system, investment flows, etc.), but the state should also regulate this phenomenon (from the state's perspective, as much as possible). However, such a "regulatory" attitude of any state to this instrument denies its main value and advantage- decentralization, its independence from centralized state financial systems.

In the Russian Federation, only "fiat" money is recognized, that officially issued by the state and which is considered an official means of payment on the territory of this state. On the basis of Part 1, Article 75 of the Constitution of the Russian Federation, the official currency is the ruble in the Russian Federation. The currency issue is carried out exclusively by the Bank of Russia. The introduction and issue of other currencies in the Russian Federation is not allowed. According to Article 27 of the Federal Law of 10.06.2002, No. 86-FL "On the Central Bank of the Russian Federation (Bank of Russia) ${ }^{13}$ ", the official monetary unit (currency) of the Russian Federation is the ruble. Hence, the introduction of other monetary units on the territory of the Russian Federation, the issue of monetary surrogates, is prohibited. Therefore, in the modern period, the circulation of cryptocurrency as money (official means of payment) in Russia is illegal.

Along with it, from an economic and legal point of view, cryptocurrency could be considered as money in cases where civil circulation would use it as a means of accumulation and turnover. As noted by L.A. Lunts: "The monetary property rests not on the law, not on the direct state coercion, but on the routine actions of participants in the civil circulation/transactions" (Lunts 1948). Accordingly, such "money" is not endowed by the law with an independent payment force, not expressed in any monetary unit, and unable to act as a separate subject of monetary obligations. The cryptocurrency transactions are not subject to the legal consequences of a monetary obligation.

12 Letter from the Central Bank of the Russian Federation (Bank of Russia) dated 09/07/2017 "The use of private" virtual currencies "(cryptocurrencies). Available online: www.consultant.ru (accessed on 26 February 2021).

13 On the Central Bank of the Russian Federation (Bank of Russia): Feder. Law of 10.07.2002 No. 86-FL (as amended on 19.02.2018). Available online: http:// www.consultant.ru (accessed on 28 February 2021). 
From a legal perspective there is a question: what is the legal nature of cryptocurrency? What is its essence and how is it viewed from the state perspective and its economic and legal system? There are a number of doctrinal opinions and positions of legislation on this issue.

According to S. P. Grishaev, "cryptocurrency must be considered as electronic money, since it has some functions that are inherent in this type of currency" Grishaev (2015). On the contrary, A. K. Churilov is more inclined towards the commodity nature of cryptocurrency: "bitcoins exchanged for goods should be considered as the conclusion of a trade agreement between the parties, and for a service-a mixed agreement of sale and purchase and the service provision for compensation" (Churilov 2016). Researchers of this problem, such as A. S. Arkhireev and A. P. Podolyan, tend to view cryptocurrency as a subject of civil law relations, but its definition is not given (Arkhireeva and Podolyan 2020).

Thus, there are completely different polar doctrinal opinions on the legal nature of cryptocurrency from the civil law perspective: some consider it as property (goods), others as information that has a price, and others as property rights.

Such uncertainty in the legal nature of cryptocurrency exists not only among scientific community, but, unfortunately, also in legislation. Analysis of Art. 128 of the Civil Code of the Russian Federation (hereinafter referred to as the Civil Code of the Russian Federation), on the one hand seems to conclude that cryptocurrency, being an intangible object, means the legislator refers to property rights, more precisely to digital rights, and it seems that the change was related to the emergence of cryptocurrency in Art. 128 of the Civil Code of the Russian Federation, which was supplemented by the legislator in March 2019 with the concept of "digital rights"14". However, the Federal Law "On Digital Financial Assets, Digital Currency and Amendments to Certain Legislative Acts of the Russian Federation", adopted in July 2020 and entered into force on January 1, 2021 (hereinafter referred to as the Federal Law "On Digital financial assets") refers to digital rights as digital financial assets, and to digital currency ("a set of electronic data (digital code or designation) contained in the information system $\langle\ldots\rangle^{\prime \prime}$ ), and clause 1 of Art. 17 of the same law proposes to consider that digital currency is recognized as property ${ }^{15}$. In another article, already in the Civil Code of the Russian Federation, namely in Art. 141.1, was established that digital rights are recognized $\left\langle\ldots>\right.$ obligations and other rights $\langle\ldots\rangle^{16}$. Based on this approach of the legislator, that is, the editions of Art. 128 and Art. 141.1 of the Civil Code of the Russian Federation and Art. 1, 17 of the Federal Law "On Digital Financial Assets", we cannot categorically state:

(1). If the legislator classifies cryptocurrency as objects of civil law as digital rights;

(2). If the legislator classifies cryptocurrency as an object of civil law as property;

(3). If the legislator classifies cryptocurrency as objects of civil law as property rights.

Along with it, the question about the turnover capacity of the object remains open. Calculation in cryptocurrency, i.e., its counter-provision for the transferred goods, performed work and provided services in the Russian Federation is prohibited under penalty of accountability ${ }^{17}$. In other words, the Federal Law "On Digital Financial Assets", establishing that digital financial rights are property, simultaneously establishes that the property cannot be a means of payment, exchange for goods and services. Such a characteristic of this property is rather strange. Thus, cryptocurrency is not recognized as a legal tender in the territory of the Russian Federation. This provision is in internal conflict with part 3, Art. 1 of the Federal Law "On Digital Financial Assets", which specifies that digital

14 See article 128 of the Civil Code of the Russian Federation (part one) of 30.11.1994 No. 51-FL (as amended on 08.12.2020). Available online: www.consultant.ru (accessed on 16 January 2021).

15 See article 1 and article 17 of the Federal Law of 31.07.2020 No. 259-FL “On digital financial assets, digital currency and on amendments to certain legislative acts of the Russian Federation". Available online: www.consultant.ru (accessed on 16 January 2021).

16 See article 141.1. Of the Civil Code of the Russian Federation (part one) of 11/30/1994 No. 51-FL (as amended on 12/08/2020). Available online: www.consultant.ru (accessed on 16 January 2021).

17 See article 14 of the Federal Law of July 31, 2020 N 259-FL “On digital financial assets, digital currency and on amendments to certain legislative acts of the Russian Federation". Available online: www.consultant.ru (accessed on 16 January 2021). 
currency can be accepted as a means of payment ${ }^{18}$. It turns out that it is possible to own a cryptocurrency by paying tax to the state, provided that transactions are performed with it (i.e., cryptocurrency acts as an investment tool); however, full-fledged operations cannot be performed by using it (as a means of payment, exchange for goods, work and services). On this basis, we can say that the Russian legislator approached the issue of legalizing the cryptocurrencies turnover in the Russian Federation with caution, and this fact is related to such partial measures regarding its legal regulation.

\subsection{Discussion}

In terms of the current Russian legislation:

1. Cryptocurrency is not legal tender in the Russian Federation.

The main difference between cryptocurrency and traditional money is that cryptocurrency is issued (generated) not by the central issuer represented by the Bank of Russia, but by all network participants i.e., miners. As noted by A. I. Savelyev: "The legal tender status allows you to pay off any monetary obligation on the territory of the Russian Federation by virtue of the law, without expressing the will of the creditor. All other types of payment (counter-provisions) that do not have the status of legal tender must be directly approved by the creditor" (Savelyev 2017). However, the concept of a means of payment is broader than the concept of money. Means of payment in Russia are also electronic money and foreign currency.

2. Cryptocurrencies are not electronic money.

Confusion is happening very often between the concepts of "cryptocurrency" and "electronic means/money".

The main difference between cryptocurrency and electronic money is that cryptocurrency is not denominated in any classic currency, while electronic money is, first of all, money (that is, denominated in a currency) that has been previously provided by one person (by the person who provided the funds) to another person who takes into account information on the amount of funds provided without opening a bank account (to the person under obligation) to fulfill the monetary obligations of the person who provided the funds to third parties and in respect of which the person who provided the funds has the right to transmit orders exclusively using electronic means of payment ${ }^{19}$.

The second significant difference between cryptocurrency and electronic money is the absence of an intermediary when performing transactions with cryptocurrencies, while settlements of electronic money transfers require the mandatory participation of an operator who verifies the payment.

Nevertheless, the desire of economic entities to free themselves from intermediaries as represented by the state and banks in this area, and the migration trend of all money into digital form, raise the issue of legally recognizing cryptocurrency as a means of payment in the Russian Federation.

The means of payment as a tool of financial transactions in the Russian Federation is also regulated by the provisions of the Federal Law No. 161-FL dated 27 June 2011 "On the National Payment System" (hereinafter referred to as the Federal Law "On the National Payment System" $)^{20}$. Some authors agree that there is no need to secure the status of an alternative means of payment for cryptocurrency. In their opinion, in terms of the economic security, it is simply harmful. Cryptocurrency is one of the most volatile assets. There are also practical difficulties: choosing the opposite approach will require a radical reform of the current Federal Law "On the National Payment System". This is due to the fact that

18 See part 3 of article 1 of the Federal Law of July 31, 2020 N 259-FL "On digital financial assets, digital currency and on amendments to certain legislative acts of the Russian Federation". Available online: www.consultant.ru (accessed on 16 January 2021).

19 See article 3 of the Federal Law of 27.06.2011 No. 161-FL (as amended on 18.07.2017) "On the National Payment System". Available online: www.consultant.ru (accessed on 28 February 2021).

20 Federal Law of 27 June 2011 No. 161-FL (as amended on 18 July 2017) “On the National Payment System”. Available online: www.consultant.ru (accessed on 28 February 2021). 
cryptocurrency does not fall under the definition of electronic money, which is given in paragraph 18, Art. 3 of the Federal Law, and also does not fall under the definition of a payment system set out in paragraph 20, Art. 3 of the same law.

\subsection{Summary}

As you can see, the new law "On digital financial assets" raises many questions, inconsistencies and internal contradictions. According to some business community experts and legal experts, the law is "crude". Undoubtedly, we still have to analyze the law enforcement practice of this regulatory legal act, however, opinions are already being heard that from the date of its entry into legal force (from 1 January 2021), the entity activities associated with cryptocurrency will become difficult and problematic, which endangers the fact of a digital asset circulation. In this connection, according to many specialists and experts, it is necessary to revise the law, especially in terms of its taxation, revise the rules for its issuance and consider the possibility of using it (though limited at first) as a legal means of payment for goods and services. A number of European researchers have also proposed the need to regulate the national mechanism of taxation of cryptocurrency in terms of the need to pay tax to entities that mine and transact with cryptocurrency. In particular, it is proposed to establish a tax for individuals when selling and buying cryptocurrency, a tax for persons engaged in mining and a value-added tax for subjects of crypto-transactions (Náñez Alonso 2019).

The same legal uncertainty of the cryptocurrency nature and transactions is observed in the legal practice. Of course, this situation is mediated by the legislative contradictions, proceeding from the fact that judicial precedent in Russia is not officially recognized as a source of law. Nevertheless, in various legal conflicts, legal practice provides assistance in their solution (through the adoption of special reviews and resolutions of the Plenum of the Supreme Court of the Russian Federation-hereinafter referred to as the SC of RF). As the analysis of the resolution of the SC of RF of 07.07.2015 No. 32 (as amended of 02.26.2019) "On legal practice in cases of legalization (laundering) of funds" shows the target of crime along with classical objects and includes "funds, converted from virtual assets (cryptocurrency) obtained as a result of a crime ${ }^{21}$," that is, the SC of RF recognizes cryptocurrency as an object of relations, though criminal.

As the global effect of the cryptocurrency advent and circulation is of interest to the situation with cryptocurrency, what is the attitude towards it according to law in foreign countries? In the North American states (USA and Canada), cryptocurrency is considered a valuable property subject to tax, and Japan, back in 2016, recognized cryptocurrency as a legal tender (Zykova and Lobach 2020). In Argentina, Germany, Sweden and Switzerland, cryptocurrency is viewed as a counterpart of foreign currencies and is accepted as a means of payment (Konyagina 2019). However, in most states, the legal regulation issues of cryptocurrency are at the stage of discussion and draft legislation in this area.

We tend to agree with the opinion of M. N. Konyagina, who assumes that their (cryptocurrencies-author's note) regulation yielded positive results. It is necessary not to prohibit cryptocurrencies at the state level and not to deprive the freedom of individuals who use these tools, but to carefully approach the issue of regulation and creation of a legal framework" (Konyagina 2019).

\section{Cryptocurrency as an Object of Islamic law: The Pros and Cons}

\subsection{Theory}

A further topic for discussion of the cryptocurrency problem is its place in Islam in terms of permissibility or prohibition in economic relations, where devout Muslims are party to it. The Islamic world also did not keep apart from the influence of the processes developing around the phenomenon of cryptocurrencies.

21 See clause 1 of the Resolution of the Plenum of the Supreme Court of the Russian Federation dated 07.07.2015 No. 32 (as amended on 26.02.2019) "On judicial practice in cases of legalization (laundering) of money or other property acquired by criminal means and on the acquisition or sale of property, knowingly obtained by criminal means". Available online: www.consultant.ru (accessed on 28 February 2021). 
Initially, we note that a number of modern scholars recognize intellectual rights in the Shariah (Usmani 2015).

We do not naturally find references to cryptocurrency in the text of the Holy Quran and in the Hadiths of the Prophet ${ }^{22}$ (peace and blessings of Allah be upon him). In this connection, on this issue we are forced to turn to other lower sources of the Muslim system of law: "Ijme" (unanimous opinion of Islamic scholars living in the same period of time, who have come to an agreement in any provision of the Sharia) and "Kiyas" (process of judgment by analogy).

As for ijma, on the basis of which decisions are made on various life issues and religious rituals of Muslims, in the case when there is no direct regulation of these issues in the Holy Quran and in the Hadiths of the Prophet (peace and blessings of Allah be upon him), today there is no unanimous opinion of Islamic scholars as to whether activities related to cryptocurrency circulation are prohibited ("haram") or, on the contrary, permitted ("mubah"). Consequently, in such realities, researchers of this issue, as a rule, turn to qiyas judging by analogy, and they attempt to understand the essence of such a phenomenon as cryptocurrency in terms of its permissibility or prohibition for devout Muslims.

In general, in Islamic law ("usul al fiqh") there is the following scale for assessing actions and behavior in relation to economic activity:

(1). Mandatory ("fard" or "wajib"), for example, payment of "zakyat" (mandatory annual payment from a Muslim's income);

(2). Desirable ("mustahab" or "mandub"), for example, granting a delay in debt payment;

(3). Permissible ("mubah"), for example, conclusion of a permissible contract;

(4). Undesirable ("makruh"), for example, excessive wastefulness;

(5). Forbidden ("haram"), for example, setting interest on a loan (usury-"riba").

Actions subject to the prohibition of transactions with a certain type of property are established in the Holy Quran (Syukiyaynen 2006).

It is well known that property is inherent in such features as value. It is valuable from the Islamic law perspective if it is possible, as a result of its use, to extract useful properties for a person, and "if it is of value (useful qualities permitted by Sharia), then the related transactions are valid, otherwise they are recognized as null and void, since property with prohibited properties cannot be in circulation between Muslims and does not enjoy legal protection" (Syukiyaynen 2006). Regarding legal protection, including property, its basis is established in the Holy Quran: "And do not devour one another's property unjustly, nor give bribery to the judges that you may knowingly eat up a part of the property of others sinfully" (verse 188 Section 2) ${ }^{23}$ and in the Sunnah The Messenger of Muhammad ${ }^{24}$ (peace and blessings of Allah be upon him): "Abdullah (ibn Mas'ud), may Allah be pleased with him, narrates that the Messenger of Allah (peace and blessings of Allah be upon him) said: "Whoever takes a false oath in order to grab another man's (or his brother's) property, then Allah will be angry with him" $<\ldots>^{25 "}$.

In general, the issue of cryptocurrency in the Islamic world has caused a controversial reaction, but then we can see such a situation in the rest of the world. There is no consensus on this issue and there is still no universal "fatwa" (Sharia solution), which would be adhered to by representatives of the entire Islamic world.

22 Note: "Hadith" is a legend about the words and actions of the Prophet Muhammad (peace and blessings of Allah be upon him), affecting various religious and legal aspects of the life of a Muslim and the Muslim community.

23 The Holy Quran (Quran online). Available online: https://quran-online.ru/2:188 (accessed on 2 February 2021).

24 Note: The Sunnah of the Prophet (peace and blessings of Allah be upon him) are numerous examples from the life of the Messenger (peace and blessings of Allah be upon him), his actions, deeds, statements that serve as a model, a model for better behavior, a guide to action as for the whole Muslim "ummah" (community), and for each devout Muslim separately.

25 Collection of hadith "Sahih al-Bukhari" (Hadith 7445). Available online: https:/ /isnad.link/book/sahih-al-buhari/97-kniga-edinobozhiya-hadisy7371-7563/24-glava-slova-vsevyshnego-odni-lica-v-tot-den-budut-siyat-i-vzirat-na-svoego-gospoda (accessed on 2 February 2021). 


\subsection{Discussion}

As cryptocurrency is a new phenomenon for Islamic law, the decision on its permissibility or prohibition should be taken by modern scientists within the framework of the four religious and legal schools ("mazhab"). In general, there are three major points on this matter:

1. Cryptocurrency is prohibited in Islam.

There are a number of Sharia decisions prohibiting any transactions with cryptocurrencies (Abubakar et al. 2018; Yussof and Al-Harthy 2018; etc.). The head of the religious establishment in Egypt $^{26}$ made such a decision. We point out some theses of this "fatwa" 27 with the corresponding comments:

- All operations with cryptocurrency are not allowed, since these are "hypothetical units" not backed by real assets. We have already analyzed the inconsistency of this argument in the economic block above;

- The prohibition comes from the fact that the cryptocurrency does not depend on a centralized institution and does not have a supervisory authority. We also analyzed this argument, pointing out that any new phenomenon should gradually enter the framework of the economic and legal field, and it is a hasty decision to say in its infancy that this is an uncontrollable asset;

- The fatwa was about the lack of mass distribution that complicates the life for individuals and legal entities using cryptocurrency. This thesis contains an inherent contradiction: no need to distribute this means of payment, because it is not widespread. Deliberate tautology is used for hyperbolic weakness of the argument;

- The lack of price standard status on the part of cryptocurrency in the economic arena. It is an erroneous decision to ban cryptocurrency due to lack of the specified status, for one should speak about the prospects, and not about the current state;

- Cryptocurrency is a high-risk asset. Indeed, today investing in cryptocurrencies is an extremely risky investment, but do not forget that cryptocurrencies are very different, including crypto assets, as well as the fact that some of them are limited. If we assume that in 15-20 years the production of bitcoins will become impossible after reaching 21 million units, then we can expect the stabilization of its rate, all other things being equal, and subsequently the risks should decrease.

2. Cryptocurrency is allowed in Islam.

Many Islamic scholars allow cryptocurrency (El Amri and Mohammed 2019, etc.). As an example, let us quote the work of Faraz Adam ${ }^{28}$, where he proves that despite bitcoin not meeting Islamic morality, since no service or product is produced in the economy but a conditional computer code is financed, in general, these transactions are allowed. The reason why he does not classify cryptocurrency as prohibited is the following: in accordance with Islamic law, bitcoin can be amounted to property, as people see it as a certain value for them, as it was given above, and it has legal value, as there is no apparent contradiction to Sharia. However, according to the author, bitcoin does not have the attributes of means of payment. In fact, today the same bitcoin is a kind of financial instrument rather than a means of payment, which is invested in for the purpose of resale in the future, i.e., mostly an investment product.

3. The decision on the cryptocurrency has been postponed.

A number of scientists do not give a definite answer, pointing out that everything depends on what economic effect the cryptocurrency will have in the future. Today it is

26 Note: The Mufti of the Republic of Egypt is Shawki Allam.

27 The mufti of the republic explains the decree on trading electronic currency "Bitcoin" (media center in Egyptian Dar Al Iftaa, date: 1 January 2018). Available online: https:/ / www.dar-alifta.org/ar/Viewstatement.aspx?sec=media\&ID=5617 (accessed on 7 February 2021).

28 Faraz Adam. Bitcoin: Shariah Compliant? Available online: https://afinanceorg.files.wordpress.com/2017/08/research-paper-on-bitcoin-muftifaraz-adam.pdf (accessed on 27 October 2020). 
difficult to predict it and in the Shariah, the usefulness of any phenomenon for the economy (and therefore for people) plays an important role when it comes to this.

Based on these three positions, it seems appropriate that cryptocurrency has a certain value in the Shariah. For example, in the "Hanafi mazhab" (religious and legal school), it is enough for a certain asset to be recognized as a means of exchange for another value, which is inherent in cryptocurrency: it can not only be bought or sold, but can be used to purchase goods. Initially, gold and silver are the classic mediums of exchange, but if something else becomes widespread and used in society as a universal element, then it is recognized as a legal medium of exchange in Islam.

The high circulation risk inherent in cryptocurrency also cannot be an argument of the Sharia order, since the prohibition of risk will play its legal role only when it passes into the degree of "garar 29 ". For example, forwards, futures, options, insurance and more are prohibited in Sharia for this reason. Basically, such restrictions are based on the following examples of everyday life and relationships between Muslims at the dawn of Islam: the sale of an unborn camel in the womb, a bird that had not yet been caught, etc. It was the Prophet Muhammad (peace and blessings of Allah be upon him) who forbade "garar" where we find evidence in various collections of hadiths ${ }^{30}$. Therefore, the cryptocurrency-related risk does not apply to "garar", as it does not come from information asymmetry, but is linked with the market situation.

If we consider cryptocurrency within the framework of the topic related to the goals of Sharia, then a number of questions arise here, for the system where the state central bank is engaged in money-lending does not correspond to the Islamic economy. When it comes to cryptocurrency, initially there is no element of riba (usury/money-lending) prohibited in Islam by its main source-the Holy Quran ${ }^{31}$. As a result, everything is in favor of cryptocurrency here.

Speaking of the possible spread of cryptocurrency-related criminal actions, then Sharia initially prohibits any activities where the subject of the transactions is goods, works or services prohibited in Islam (drugs, contract killings, prostitution, etc.). Therefore, according to Sharia this argument cannot be applied within the cryptocurrency analysis.

\subsection{Summary}

As a result, one should highlight a number of remaining problems that can be referred to as the reason for criticizing the cryptocurrency according to Islam:

1. Speculative component.

However, as noted above, it is not applicable to all cryptocurrencies. On the other hand, the same bitcoin is limited in its production, which gives grounds to count on reduction in investment risks in the long term. In any case, it does not take this asset outside the "halal" (permissibility).

2. Complete anonymity of parties to transactions.

The mechanism to address possible contentious situations is unclear; for example, the question remains open as to who should be contacted in case of defective goods that were purchased. Even if it is a solvable problem, which institution will be involved in this dispute resolution? Even this provision does not fundamentally bring the cryptocurrency out of the category permitted by Sharia.

3. Lack of communication with the real sector of the economy.

The production of cryptocurrency today involves enrichment on the rate difference only, but in the state economy there are no significant events leading to positive actions.

29 Note: "Garar" is such a degree of uncertainty when information asymmetry occurs for one of the parties to the transaction.

30 See Collection of hadith "Abi Daud" (Hadith 3382). Available online: https://isnad.link/book/sunan-abu-dauda/17-kniga-prodazh-hadisy-3326-3 570 (accessed on 25 January 2021).

31 See The Holy Quran (verse 275, Section 2 "Cow”). Available online: https: / quran-online.ru/2:275 (accessed on 3 March 2021). 
This item may result in reluctance to invest in cryptocurrency, but, nevertheless, it still does not take it out of the "halal" category.

4. The problem of legality.

An important issue in the Shariah is the legality of the funds issuance outside the state order (system). At this time, it remains a matter of discussion among specialists in the field of Islamic finance. We assume that it is necessary to closely follow the practice, as positive and negative effects may come to light that will make it possible to objectively assess the values for economic entities including the state.

\section{Cryptocurrency: money or goods?}

Disputes continue over the question of whether cryptocurrency is a commodity or a means of payment. With regard to the legal aspect, then today we can definitely urge that the recognition of cryptocurrency as property (goods) takes place in the USA, Australia (Skryleva and Shnyakin 2017) and some countries of the world. Cryptocurrency is recognized in Japan, Hong Kong, Singapore, the Virgin Islands (Skryleva and Shnyakin 2017) and a number of non-governmental organizations and bodies such as the European Court of Justice, an international organization "FATF" (Financial Action Task Force on Money Laundering (FATF)) (Zeinelgabdin and Akhmetbek 2020) and others as a currency or means of payment.

According to Islam and Sharia, we assume that it is necessary to further analyze the practice of using cryptocurrency and its impact on the economy in order to make a final decision regarding its permissibility or prohibition in correlation with various activities and related upcoming consequences.

\section{Conclusions}

In recent years, cryptocurrencies have become one of the trending currencies, as evidenced by the increased attention to them from almost all the developed countries of the world. There are a number of relevant factors, including the hopes pinned on them as new tools of financial and settlement operations and investments.

Economically, nowadays, cryptocurrency is a rather controversial financial instrument: on the one hand, it has great investment attractiveness, but on the other hand, it is subject to great volatility and seems to be a rather risky financial asset.

As a further aspect of economic research on the stated topic, the following can be highlighted:

1. The need for methodological developments, taking into account the patterns of turnover in assessing and predicting the rate of cryptocurrencies, which will make it possible to correctly calculate their development trends, because even experts make mistakes in their rate forecasts. A rather bold, updated prediction was made about the growth of bitcoin by the end of the 3rd quarter of 2018 to USD 11,000 in one recent scientific article (Safiullin et al. 2018). Despite the high quality of the authors in their research, hopes for such a bitcoin rate did not come true, as there was a gradual devaluation during this period to USD $6500^{32}$.

2. Solutions are presented in the balance sheet related to cryptocurrency, the development of which is only at the initial stage (Pinskaya and Tsagan-Mandzhieva 2018; Tsagan-Mandzhieva 2017).

3. A detailed analysis of the cryptocurrency investment, which has an insufficient amount of research in the scientific and pseudoscientific environment (Borisova 2017).

4. Studying cryptocurrency as a type of economic activity, as today it is a serious business, including mining, initial placement, trading, funds and additional services. Articles on calculating the economic feasibility of mining are just beginning to appear in scientific journals (Naidis and Nestrugina 2018), which seems to be a recent trend.

32 Chart of Bitcoin (BTC) to the dollar (USD) for 2018. Available online: https:/ / www.calc.ru/grafik-Bitcoin-k-dollaru-za-2018.html (accessed on 25 February 2021). 
From a legal standpoint, cryptocurrencies have not yet found their consistent consolidation and further legal regulation in the Russian legislation. It seems that the legal regulation of this institution will systematically develop depending on what application and results of its turnover the cryptocurrency will have in the future.

Finally, the Islamic interpretation of the cryptocurrency phenomenon boils down to the absence of a single, consistent explanation of it from the perspective of Islam and Sharia as an object of permissibility (or prohibition) of transactions with it. However, in the meantime, we note the extreme weakness of the arguments of Muslim leaders expressly prohibiting cryptocurrency, as explained above. In our opinion, it is necessary to further follow the practice of using cryptocurrency and its impact on economic and social processes in order to make a final decision regarding its permissibility or prohibition in correlation with the types of activity and the related upcoming consequences.

Author Contributions: Conceptualization, S.S. and H.I.; methodology, H.I.; formal analysis, S.S.; investigation, H.I.; data curation, S.S.; writing-original draft preparation, S.S. and H.I.; writingreview and editing, S.S. and H.I. Both authors have read and agreed to the published version of the manuscript.

Funding: This research was carried out within the framework of the implementation of the grant of the Chechen State Pedagogical University for young scientists and students for 2021.

Institutional Review Board Statement: Not applicable.

Informed Consent Statement: Not applicable.

Data Availability Statement: Not applicable.

Conflicts of Interest: The authors declare no conflict of interest.

\section{References}

Abubakar, Yusuf Sani, Ahmad Faosiy Ogunbado, and Mpawenimana Abdallah Saidi. 2018. Bitcoin and its legality from Shariah point of view. Journal of Management 1: 13-21. [CrossRef]

Arkhireeva, Anastasia Sergeevna, and Alexey Pavlovich Podolyan. 2020. The Problem of Legal Regulation of Cryptocurrency in the Russian Federation//Epomen. pp. 28-35. Available online: http:/ / epomen.ru/issues/2020/35/Epomen-35-2020.pdf (accessed on 17 January 2021).

Borisova, Olga Viktorovna. 2017. Cryptocurrency as a means of increasing the attractiveness of Russian business. Business Strategy 41: $17-21$.

Chohan, Usman W. 2019. Are Stable Coins Stable? Notes on the 21st Century (CBRi). Available online: https:/ / papers.ssrn.com/sol3 /papers.cfm?abstract_id=3326823 (accessed on 29 April 2021).

Churilov, Alexey Yurievich. 2016. On the question of the legal nature of cryptocurrency. Economy and Law 9: 93-99.

Echarte Fernández, Miguel Ángel, Sergio Luis Náñez Alonso, Javier Jorge-Vázquez, and Ricardo Francisco Reier Forradellas. 2021. Central Banks' Monetary Policy in the Face of the COVID-19 Economic Crisis: Monetary Stimulus and the Emergence of CBDCs. Sustainability 13: 4242. [CrossRef]

El Amri, Mohamed Cherif, and Mustafa Omar Mohammed. 2019. The Analysis of Cryptocurrency Based on Maqasid al-Shari'ah. Halal Cryptocurrency Management. Cham: Palgrave Macmillan, pp. 119-131.

Golenko, Alina Andreevna, and Irina Alexandrovna Kislaya. 2017. A wonder of scientific and technological progress-Cryptocurrency. New Science: Strategies and Vectors of Development 1: 78-81.

Grishaev, Sergey Pavlovich. 2015. Evolution of Legislation on Objects of Civil Rights. Available online: http://www.consultant.ru (accessed on 6 February 2021).

Hayek, Friedrich August van. 1996. Private Money. Moscow: Institute of the National Model of the Economy, 229p.

Konyagina, Maria Nikolaevna. 2019. Foreign experience in regulating the circulation of cryptocurrencies. Architecture of finance: Fast and furious development of the economy in conditions of external shocks and internal contradictions. Paper presented at Collection of materials of the X Anniversary International Scientific and Practical Conference, Saint Petersburg, Russia, April 11-13; pp. 34-38. Available online: https: / /www.elibrary.ru/item.asp?id=42768254 (accessed on 17 January 2021).

Kurylenok, Kirill Leonidovich. 2019. New monetarism "and" cryptomonetarism: In search of the economic theory of cryptocurrency. Banking Bulletin 11: 19-26.

Lunts, Lazar Adolfovich. 1948. Monetary Obligation in the Civil and Conflict Law of Capitalist Countries. Moscow: Legal Department of the Ministry of Justice of the USSR, 215p.

Naidis, Olga Alexandrovna, and Ekaterina Alexandrovna Nestrugina. 2018. Calculation of the profitability of cryptocurrency mining depending on the initial capital and additional costs. Controlling: Management Technologies 2: 20-26. 
Náñez Alonso, Sergio Luis, Javier Jorge-Vazquez, and Ricardo Francisco Reier Forradellas. 2021. Central Banks Digital Currency: Detection of Optimal Countries for the Implementation of a CBDC and the Implication for Payment Industry Open Innovation. Journal of Open Innovation: Technology, Market, and Complexity 7: 72. [CrossRef]

Náñez Alonso, Sergio Luis, Miguel Ángel Echarte Fernández, David Sanz Bas, and Jarosław Kaczmarek. 2020. Reasons Fostering or Discouraging the Implementation of Central Bank-Backed Digital Currency: A Review. Economies 8: 41. [CrossRef]

Náñez Alonso, Sergio Luis. 2019. Activities and Operations with Cryptocurrencies and Their Taxation Implications: The Spanish Case. Laws 8: 16. [CrossRef]

Nedorezkov, Vyacheslav Viktorovich. 2017. Cryptocurrencies based on blockchain technology: Problems of legal regulation. Banking Law 4: 45-49.

Pekhtereva, Elena Alexandrovna. 2018. Prospects for the use of blockchain technology and cryptocurrency in Russia. Economic and Social Problems of Russia 1: 71-95.

Pinskaya, Milyausha Rashitovna, and Kermen Nikolaevna Tsagan-Mandzhieva. 2018. Taxation of income from activities related to cryptocurrencies. Economics. Taxes. Right 11: 138-48.

Rallo, Juan Ramón. 2019. Bitcoin, ¿Una Alternativa al Dólar? Cato Institute. Available online: https:/ /www.elcato.org/bitcoin-unaalternativa-al-dolar (accessed on 29 April 2021).

Safiullin, Marat Rashitovich, Leonid Alekseevich Elshin, and Aliya Aidarovna Abdukaeva. 2018. Development of a stochastic model for medium-term forecasting of the rate of cryptocurrencies (for example, bitcoin). Finance and Credit 24: 1046-60. [CrossRef]

Sanz Bas, David. 2020. Hayek and the cryptocurrency revolution. Iberian Journal of the History of Economic Thought 7: 15-28. [CrossRef]

Savelyev, Alexander Ivanovich. 2017. Cryptocurrencies in the system of objects of civil rights. Law 8: 136-53.

Sazhina, Musa Arkadyevna, and Svyatoslav Vladimirovich Kostin. 2018. Cryptocurrency: The Triumph of Desires over Reality. Bulletin of Moscow University 1: 32-45.

Shcherbik, Evgeny Efimovich. 2017. The phenomenon of cryptocurrencies: The experience of a systemic description. Concept 1: 56-64.

Shevchenko, Julia Mikhailovna. 2018. Cryptocurrencies as a tool for attracting investments: Problems and prospects. Innovative Technologies in Mechanical Engineering, Education and Economics: Electronic Journal 1: 164-67.

Shmigidin, Bogdan Romanovich, and Elena Arkadyevna Borkova. 2019. Reasons for investing in cryptocurrency in 2018-2019 and the possibilities of its use in different countries. Economy and Business: Theory and Practice 58: 155-58.

Skryleva, Daria Dmitrievna, and Kirill Vyacheslavovich Shnyakin. 2017. The influence of the bitcoin cryptocurrency on the monetary system. Bulletin of Young Scientists of SSEU 36: 87-91.

Svetovtseva, Tatyana Ananyevna, Sima Aslambechevna Mamiy, and Tatyana Alexandrovna Bochkova. 2018. The role of cryptocurrency in the modern economy. News of the South-West State University. Series: Economics. Sociology. Management 8: 95-102.

Swan, Melanie. 2017. Blockchain: A New Economy Scheme: [Translated from English]/Melanie Swan. Moscow: Olymp-Business, 234p.

Syukiyaynen, Leonid Rudolfovich. 2006. Muslim property right: Legal understanding of religious postulates. Russia and the Muslim World 3: 139-149.

Tsagan-Mandzhieva, Kermen Nikolaevna. 2017. On approaches to taxation of operations with cryptocurrencies. Taxes and Taxation 11: 9-17.

Ushakova, Nadezhda Evgenievna. 2019. Cryptocurrency and its impact on the world economy on the example of Bitcoin. Management Issues 1: 57-64. [CrossRef]

Usmani, Muhammad. 2015. Figh Al-Buyu. Karachi: Maktaba Ma'ariful Quran, 1258p.

Yankovsky, Roman Mikhailovich. 2020. Cryptocurrencies in Russian law: Surrogates, "other property" and digital money. Law. Journal of the Higher School of Economics 4: 43-77. [CrossRef]

Yussof, Sheila Ainon, and Abdullah Al-Harthy. 2018. Cryptocurrency as an alternative currency in Malaysia: Issues and challenges. Islam and Civilisational Renewal 274: 1-18. [CrossRef]

Zeinelgabdin, Altay Boltaykhanovich, and Erlan Akhmetbek. 2020. Cryptocurrency and blockchain technology-New realities of the modern economy. Economy: Strategy and Practice 15: 111-25.

Zykova, Tatiana Alexandrovna, and Dmitry Vladimirovich Lobach. 2020. The practice of using cryptocurrencies in foreign countries. International Journal of the Humanities and Natural Sciences 4-2: 162-68. 